\title{
Reverse mentoring and peer coaching as professional development strategies
}

\section{La tutoría a la inversa y el coaching entre pares como estrategias para el desarrollo profesional}

\author{
Nohora Inés Porras ${ }^{1}$ \\ Lenys Smith Díaz ${ }^{2}$ \\ Marlen María Nieves ${ }^{3}$
}

Citation/ Para citar este Artículo: Porras, I., Díaz, L., \& Nieves, M. (2018). Reverse mentoring and peer coaching as professional development strategies. Colomb. Appl. Linguistic. J., 20(2), pp. 169-183.

Received: 07-Nov.-2017 / Accepted: 15-Jun.-2018

DOI: https://doi.org/10.14483/22487085.12422

\begin{abstract}
Presently, learning a foreign language is an essential academic requirement in several contexts, hence the importance and the need for effective teaching in this field at all educational levels starting with the first years of school. As a consequence, teaching and learning in elementary school is a key issue to success in the learner's future language learning. However, at some public elementary schools in Colombia there are many factors that hinder this process. One of them is the fact that most of the teachers who are in charge of teaching English in elementary schools are not sufficiently trained to do this job (McNulty \& Quinchía, 2007). For this reason, the aim of this study is to strengthen the pedagogical practices of the participating teachers. Guided by the theoretical foundations of peer coaching and reverse mentoring, this mixed-methods study examined strategies for professional development via results of an English test, class observations, questionnaires, focus groups, interviews, and journals. Findings show the effectiveness of the proposal in terms of the professional growth of the participants who exchanged teaching experiences and pedagogical tools within a mutual and trusting atmosphere. This helped them to enhance their knowledge about teaching a foreign language and test new teaching techniques and strategies to favor their students' language learning.
\end{abstract}

Keywords: in-service teachers, peer coaching, pre-service teachers, professional development, reverse mentoring

\section{Resumen}

En la actualidad, el aprendizaje de una lengua extranjera es un requisito académico esencial en diferentes contextos. De allí la importancia y la necesidad de llevar a cabo procesos de enseñanza efectivos en todos los niveles educativos iniciando por los primeros años de escolaridad. La enseñanza y el aprendizaje de las lenguas en la básica primaria es un asunto crucial ya que es la base para el futuro aprendizaje de la lengua. Sin embargo, en algunas escuelas del sector oficial en Colombia hay muchos factores que afectan este proceso. Uno de ellos es el hecho que la mayoría de los profesores encargados de enseñar inglés en la básica primaria no están lo suficientemente cualificados para hacerlo (McNulty \& Quinchía, 2007); por esta razón, el propósito de este estudio es fortalecer las prácticas pedagógicas de los profesores participantes. Esta es una investigación con un enfoque mixto en la cual se utilizaron

1 Universidad Cooperativa, Bogotá, Colombia. niporrasg@yahoo.com

2 Universidad Cooperativa, Bogotá, Colombia. lenys.diazs@campusucc.edu.co

3 Universidad Cooperativa, Bogotá, Colombia. marlen.nieves@campusucc.edu.co 
como instrumentos de recolección de información una prueba diagnóstica de inglés, observaciones de clase, cuestionarios, grupos focales, entrevistas y diarios de campo. El coaching entre pares y la tutoría a la inversa fueron utilizados como fundamentos teóricos y estrategias para el desarrollo profesional de los profesores. Los resultados muestran la efectividad de la propuesta en términos de crecimiento profesional de los participantes quienes intercambiaron experiencias de enseñanza y herramientas pedagógicas en una atmósfera de confianza y trabajo mutuo. Esto contribuyó a ampliar su conocimiento sobre la enseñanza del inglés y a probar nuevas técnicas y estrategias de enseñanza que favorecen el aprendizaje de la lengua en los estudiantes.

Palabras clave: coaching entre pares, tutoría a la inversa, desarrollo profesional, profesores en ejercicio, estudiantes practicantes

\section{Introduction}

Teaching English in Elementary schools is mandatory in Colombia. The national law establishes that students should start this process in first grade. According to Lineamientos Curriculares: Idiomas Extranjeros (Ministerio de Educación Nacional, 1999) "La Ley 115 determina, a partir del artículo 67 de la Constitución, [...] la necesidad de promover la adquisición de por lo menos una lengua extranjera desde el ciclo de primaria" (p. 4). Furthermore, according to the Colombian National standards for foreign languages, by the time students finish fifth grade they should have reached an A2 level of proficiency in the language; achieving these results, however, has been challenging. This may be due, in part, to the time assigned for the English classes, the lack of a structured curriculum in the English area for elementary school, the teachers' limited linguistic and didactic knowledge for teaching English, few opportunities for professional development in the English area, and the lack of resources in some schools, among others. In fact, there are many factors that affect this situation; however, in this study we focus on the teaching process and the qualifications that elementary school teachers have for teaching the foreign language.
Most elementary school teachers in Colombia are qualified in education and not specifically in teaching English as a foreign language; as a result, most of them have neither the competence in the foreign language nor the appropriate methodology. However, they are required to do so, but in most cases, classes are not taught following the appropriate procedures since teaching English to children requires a specific methodology and didactics. According to Álvarez, Cárdenas and González (2015):

$12 \%$ of the surveyed universities discuss the lack of coverage of the [professional development programs] in relation to primary school teachers. In general, these programs have been offered to teachers of secondary education excluding primary school teachers, who despite their low level of proficiency in English, have had to assume a high responsibility to teach English in order to reach the standards for foreign languages. (p. 198) ${ }^{4}$

In other studies of professional development in Colombia (e.g., Chavez \& Fernandez, 2016); McNulty \& Quinchía, 2007), it has been found that public elementary school teachers have limitations both linguistically and pedagogically. According to McNulty and Quinchía (2007) "teachers had limited or unrelated educational preparation, insufficient training and target language preparation" (p. 132). This suggestion has a potentially strong influence in the teaching and learning of foreign languages. In this way, it is paramount that teachers be sufficiently qualified since they play an important role as facilitators of the teaching and learning process and, equally, are a source of input for their students especially at the elementary level.

On the other hand, even though the Ministry of Education has provided training for English teachers, the coverage has not been enough to impact particularly public elementary schools, so not many meaningful results have been achieved yet. Álvarez et al., (2015) found out that "between the year of enactment of the law and the implementation of Colombia Bilingüe, the language teaching training programs continue without impacting the primary

\footnotetext{
4 Authors' translation.
} 
education" (p. 181) $)^{5}$. For this reason, reflecting on this issue and taking into consideration that the attempts made by the Colombian government to enhance this situation have not been enough, this study emerges as a way of supporting teachers in this task in order to help them improve their teaching practices in the English classroom.

In order to achieve that support, we implemented both reverse mentoring and peer coaching as strategies for teachers' professional development. These strategies were implemented with the pre-service teachers from a private university in Bucaramanga-Colombia, who were carrying out their first English teaching practicum and a group of inservice teachers from a public school in the same city. The purpose of the present study was to describe the extent to which reverse mentoring and peer coaching supported teachers' professional growth. For the sake of determining the benefits of these strategies, a study was developed in four stages. In the first stage, we characterized the in-service teachers' practices through class observations and determined their level of English language proficiency through an English test. Additionally, we applied a questionnaire in order to collect data regarding the in-service teachers' personal information, educational background, teaching experience, teaching strategies, needs and interest in professional development. Based on these data, we designed the reverse mentoring strategy in which the in-service teachers observed the preservice teachers' practicum in order to gain some insights into how to teach English in elementary school. During their observations, they were asked to keep a journal with their field notes which helped them to reflect on the process. In the third stage, the in-service and the pre-service teachers worked collaboratively using the peer coaching strategy. In the final stage, we analyzed the data using a triangulation method. With these data, findings were established and conclusions arose.

\section{Theoretical Consideration}

For this study three main concepts were taken as the theoretical basis which will be described below:

\footnotetext{
5 Authors' translation.
}

professional development, reverse mentoring, and peer coaching.

\section{Professional Development}

Professional development in the field of education has long served as a way for educators to continuously develop and hone the skill related to their practice. In the field of teaching foreign languages is essential to have the command of the target language, to possess the didactic knowledge, to be reflective, and to inquire about one's teaching practice. That is why professional development programs have become an alternative that may contribute to strengthen teachers' professional growth. As Richards and Farrell (2005) state:

Teacher development serves as a longerterm goal and seeks to facilitate growth of the teacher's general understanding of teaching and of himself or herself as teacher. It involves examining different dimensions of one's own practice as a basis for reflective review and can hence be seen as bottom-up. (p. 4)

As such, this project discussed in this paper intended to contribute toward developing in-service teachers' language teaching instruction from observing, analyzing, and reflecting on their own and their peer's practices as a strategy for their professional development.

In Colombia there have been proposals to support teachers professionally, but taking into account some of the analysis of those initiatives, there is still a lack of complete satisfaction due to several factors such as time, range, coverage and follow up to the results of those programs. For example, recent studies on professional development for language teachers in elementary schools in Colombia show that even though the Ministry of Education through the National Bilingual Program has made several efforts to reach the bilingual goals proposed for the year 2019, they have not yet been achieved and there are still many aspects of this program that require attention (Álvarez et al., 2015; Cárdenas E Miranda, 2014; Cárdenas, González, E Álvarez, 2010; Correa E González, 2016; González, 2007; McNulty $\&$ Quinchía, 2007). One of these aspects 
has to do with teachers' qualifications. Although the government has invested in qualifying teachers, the coverage has not been enough and there are still many needs in this regard. McNulty and Quinchía (2007) state that "despite these governmental initiatives directed towards helping primary school teachers, local research studies have shown that primary school English teachers and their learners continue to face difficulties with this educational endeavor" (p. 132). Elementary school teachers require support, especially those who have not had too much contact and exposure to the target language or have not been trained methodologically to do this job. This implies some linguistic as well as a pedagogical and didactic training.

Based on our experience as researchers, teacher educators, and practicum supervisors, we have perceived some needs that elementary school teachers have regarding the teaching of English. They have often required teacher training in this area and the support of specialists. Unfortunately, professional development programs in Colombia have not been enough or if so, they have not had the impact that is expected mainly in elementary schools. As Álvarez et al., (2015) encountered in their study:

Due to the promulgation of English standards within the National Bilingual Program, training opportunities have been managed for elementary school teachers. However, it is observed that the coverage is still incipient if we compare the beneficiaries of the professional development programs with the total number of English teachers in the country. The need to expand the current coverage is quite evident for the primary and preschool levels where the compulsory nature of teaching English has been imposed in the framework of the National Bilingual Program. (p. 192) ${ }^{6}$

Similar findings have been demonstrated in other studies (Cárdenas \& Miranda, 2014; Cárdenas, González, E Álvarez, 2010; Correa E González, 2016; González, 2007). Therefore, while taking into account the previous concerns, providing

6 Translation by the authors. teachers with professional development programs that fit their needs should be one of the Colombian government's priorities as they play a fundamental role in the teaching and learning process.

According to Cely (2007), it is not enough to have bilingual rooms with a lot of resources, if teachers are not qualified. That is the case of the group of the participant teachers in this study who, in spite of being aware of the importance of becoming qualified for teaching English, haven't had the opportunity to participate in any professional development programs that help them to fulfill their needs and interests in this field. For this reason, as teacher educators, after perceiving the needs of elementary school teachers in carrying out classroom practices with appropriate procedures that teaching English to children requires, we decided to work on a proposal that could contribute to promoting better English practices that impact children's language learning.

This proposal of professional development was made based on two strategies: reverse mentoring and peer coaching. In this model, teachers become observers and reflective of their colleagues' practice as well as their own. Teachers see real practices and from that experience they analyze how they can implement them in their classroom and with their own students. In this way, it becomes a long-lasting experience. Teachers do not have a mentor who shows them the 'right' procedures for teaching the language, but their professional growth arises from their own reflection and exchange of ideas and knowledge with their peers. As Álvarez et al. (2015) claim:

There is an urgent need that teachers have an active role rather than a passive one in their own professional development, by reflecting on their own pedagogical practices and their training as such, making decisions and participating in innovation or research projects which allow them to build knowledge. (p. 178) ${ }^{7}$

From thisperspective, the concept of professional development emerges as a constructivist view in which interaction and collaborative work among colleagues foster their personal and professional

7 Translation by the authors. 
growth. Reciprocal interactions in which teachers take responsibility for their own learning, care about each other's development, demonstrate mutual commitment and share objectives, can provide an effective means of professional learning. Zwart, Wubbels, Bergen, and Bolhuis (2009) suggest that professional development can be improved through experience, observations, reflection, and exchange of professional ideas and shared problem solving.

Another essential aspect in this model is to consider teachers' needs and interests. It is necessary to notice that a golden rule in professional development programs is to ask teachers what they desire and what they need to learn in order to improve their teaching practice. As suggested by González, Montoya, and Sierra (2002),

Teachers are considered to be the cornerstones of any program because they will be the direct actors of their own professional development. Imposing agendas in professional growth may not have the results expected. Teachers would be more committed to be agents of their own development if they had more opportunities to say what they need. (p. 30)

Díaz-Maggioli (2003) claims that teachers have different needs as they progress through some professional stages, and that professional development must target their specific needs at each stage. That is why we consider beginning a professional development program (PDP) by contemplating teachers' needs results in them being more interested and committed during the process and the program becomes more organic since it is not imposed upon them, but instead develops naturally.

\section{Reverse Mentoring}

Traditionally, mentoring relationships in the organizational context have consisted of an older, senior executive providing advice and counsel to a younger, junior colleague (Bozeman $\mathcal{E}$ Feeney, 2007; Greengard, 2002; Hewlett et al., 2009a, 2009b; Kram \& Isabella, 1985; Meister \& Willyerd, 2010; Murphy, 2012; Wanberg, Welsh, \& Hezlett, 2003). Following Brewer (2016), there are several types of mentoring dynamics such as the traditional "one-on-one mentoring," "professional mentoring," "sponsoring," "cross-cultural mentoring," "peer mentoring," and "reverse mentoring" among others. Reverse mentoring is a quite new conception of mentoring and it can be defined as the kind of mentoring in which a young and less experienced person becomes the mentor of an older, senior and more experienced colleague who becomes the mentee (Murphy, 2012).

Most of the studies examining reverse mentoring have been done in organizational contexts in which a new, perhaps younger employee can provide technological and digital knowledge to more experienced colleagues who lack such knowledge. However, there are a few studies on reverse mentoring in education in which a more experienced teacher can gain knowledge from a novice one. In this study, reverse mentoring was implemented with a group of elementary school teachers who have to teach English even though they are not prepared enough to do so. As they did not possess the knowledge of how to teach a foreign language, the researchers saw the chance to provide them with an opportunity to qualify themselves using the reverse mentoring strategy. Thus, through the English Teaching Practicum, researchers carried out a qualification program in which in-service teachers observed pre-service teachers during their teaching practicum. During these observations, the in-service teachers were able to observe various methods, teaching strategies and activities used for teaching English to children. The observations were made weekly and the in-service teachers took field notes. These observations were later discussed with the pre-service teachers who explained and justified why those procedures were implemented in class. In this interaction, the in-service teachers were able to gain insight into how to teach English to children and at the same time, they became aware of how to implement such procedures with their own students.

Traditionally, mentoring has been conceived as a practice in which only one person benefits from the other; the mentee gains valuable knowledge from a colleague who is more experienced. This concept, however, has evolved and those roles have changed. Zauchner-Studnicka (2017) states that "in reverse mentoring an understanding of interpersonal 
relations being characterized by a shape of apprenticeship or hierarchy no longer fits. Instead, it turns to reciprocity as both mentor and mentee take advantage of the mentoring relationship" (p. 546). During this research project, the relationship between the pre-service teachers engaged in the role of mentors and the in-service teachers who were the mentees strengthened because the attitude of both sides was open and collaborative. The former wanted to guide the in-service teachers on English teaching didactics and were willing to do so since they were aware of their needs. For this reason, they planned their lessons using a variety of strategies in order to be good models for them.

\section{Peer Coaching}

Peer coaching is a process in which two or more teachers work towards a specific and determined purpose in order to improve and validate their practices in the classroom. According to Robbins (1991), "peer coaching is a confidential process through which two or more professional colleagues work together to reflect on current practices; expand, refine, and build new skills; share ideas; teach one another; conduct classroom research; or solve problems in the workplace" (p. 1). The contributions of peer coaching have been clearly defined by the literature (Anderson, Caswell, \& Hayes, 1994; Bowman \& McCormick, 2000; Briggs $\mathcal{E}$ Van Nieuwerburgh, 2010; Britton $\varepsilon$ Anderson, 2010; Buzbee Little, 2005; Cornett $\mathcal{E}$ Knight, 2009; Devine, Meyers, \& Houssemand, 2013; Duncan E Stock, 2010; Showers E Joyce, 1996). In these studies, it has been found that reciprocal relationships among colleagues can lead to professional growth providing them with opportunities to share and expand their expertise.

Robins (1991) presents different forms in which peer coaching can take place depending on the way the participants decide to work. It can be done in pairs, trios, or in teams who focus on different aspects related to either the curriculum, teaching strategies, teaching skills, or some specific techniques, and other outside and inside classroom practices. Additionally, this author includes some peer coaching activities such as "storytelling about teaching practices," "materials development," "coplanning lessons," "planning interdisciplinary units," "problem solving," "co-teaching lessons," and "coach as a mentor" among others.

In this research study, peer coaching was worked in pairs between expert and novice teachers: a group of experienced elementary school teachers and a group of pre-service teachers. As Robbins states (1991), "some coaching may occur between an expert and a novice or between experienced and less-experienced teachers" (p. 3).

At the beginning of the peer coaching process there was an initial meeting in which the researchers explained to the in-service and the pre-service teachers the process and the stages that it required. During a semester both groups met, exchanged ideas, and observed each other giving classes and then provided each other with feedback. In order to implement the strategy, the participants followed three stages: the pre-conference, the observation, and the post-conference. Following Robbins (1991), "some peer coaching involves two or more colleagues working together around the shared observation of teaching. In this instance, there is generally a pre-conference, an observation and a post-conference" (p. 3). In these three moments, the participant teachers of this study

arranged aspects such as the purpose of the observation, the instruments for gathering information, how the observation was going to be made and the criteria for the discussion of what was going to be observed, as well as the sessions for the observation.

Following those three steps or moments, colleagues can exchange pedagogical knowledge and teaching experiences as well as strategies to improve classroom teaching practice, because "regardless of the type or approach, peer coaching efforts all share a collaborative quest to refine, expand, and enhance knowledge about the teaching profession" (Robbins, 1991, p. 7).

\section{Methodology}

This is a mixed methods study in which quantitative and qualitative data collection 
instruments were used. According to Creswell (2014), "mixed methods involves the collection and 'mixing' or integration of both qualitative and quantitative data in a study" (p. 14). Instruments used during the study were class observations, questionnaires, focus groups, interviews, and journals. The design used was an exploratory sequential mixed method that Creswell (2014) describes as an approach in which:

The researcher first begins with a qualitative research phase and explores the views of participants. The data is then analyzed, and the information used to build into a second, quantitative phase. The qualitative phase may be used to build an instrument that best fits the sample under study, to identify appropriate instruments, to use in the follow-up qualitative phase, or to specify variables that need to go into a follow-up quantitative study. (p. 16)

\section{Participants}

The research took place at a public school in the city of Bucaramanga, Colombia. The participants were 10 elementary female school teachers selected according to their availability and willingness to participate in the study. All were full time teachers who worked in the afternoon; their ages ranged from 30 to 45 years old. All of them had more than 10 years of teaching experience; however, some were new teachers at that school. In addition, almost all of the teachers had a degree in primary education; one teacher was qualified in Spanish teaching and another specialized in psychology but none of them had studies in English teaching. The other participants were seventh semester preservice English teachers who were carrying out their English teaching practicum I at a private university in Bucaramanga. The pre-service teachers had knowledge on how to teach a foreign language but little teaching experience.

The quantitative data gathered from a teacher's survey and an English proficiency test were coded, tabulated, and then tables and bar graphs were elaborated. The variables such as the linguistic level from the in service teachers, their teaching experience, their studies, and their perceptions and beliefs about how to teach a foreign language were analyzed taking into account the percentage statistical technique. From this analysis, the results found are as described below:

Table 1: English Test Results.

\begin{tabular}{|c|c|c|c|c|c|}
\hline Teacher & Reading & Listening & Speaking & Total & Level \\
\hline T1 & 50 & 23 & 17 & $\frac{9010}{90}$ & B1 \\
\hline T2 & 39 & 21 & 15 & 75 & A2 \\
\hline T3 & 24 & 13 & 8 & 45 & A1 \\
\hline T4 & 20 & 7 & 5 & 32 & Under A1 \\
\hline T5 & 10 & 1 & 5 & 16 & Under A1 \\
\hline T6 & 20 & 2 & 7 & 29 & Under A1 \\
\hline $\mathrm{T} 7$ & 14 & 6 & 5 & 25 & Under A1 \\
\hline T8 & 21 & 5 & 5 & 31 & Under A1 \\
\hline
\end{tabular}

As shown in Table 1 above, the teachers were placed between $\mathrm{A} 1$ and $\mathrm{B} 1$ level based on the Common European Framework of Reference (CEFR), 62.5\% scored lower than the A1 level; $12.5 \%$ reached an A1 level, $12.5 \%$ got an A2 level, while $12.5 \%$ got a B1. This indicates that most of the teachers selected for this study did not have the required linguistic competence for teaching the target language.

Regarding the variable related to the teaching experience, it was found that $100 \%$ of teachers had more than 10 years of experience. Another variable analyzed was the teachers' educational background: $75 \%$ of them had a degree in Primary Education, $12.5 \%$ had a degree in Spanish Teaching and 12.5\% in Psychology. It can be highlighted that even though most of the teachers are qualified in the educational field, none of them had a degree in teaching English as a foreign language.

Concerning the teachers' perceptions and beliefs about how to teach the foreign language to children, the results from the questionnaire were: $12.5 \%$ assumed that the teaching must imply both theory and practice; $12.5 \%$ claimed that the dynamic activities are helpful; $12.5 \%$ expressed that using worksheets is useful especially for the writing skill; $12.5 \%$ considered that it is necessary to evaluate the process; $25 \%$ suggested the use of specific and attractive material, and the other $25 \%$ manifested that it is important to use didactic and technological resources. 
Regarding the qualitative data, the field notes and transcripts of the interviews and focus groups were read and analyzed in order to find the key words and to establish categories of analysis. Data were triangulated according to the explicit theory in the theoretical framework, the data provided by the participants, and the position of the researchers with the intention of understanding the situation. The participants of the present study provided all the information in their native language (Spanish) and the researchers translated their interventions.

\section{Study Design}

The study was divided into four phases as presented below.

Phase I. In this stage a consent form was first provided by the researchers and accepted by the 10 participants involved in the study. In order to characterize the in-service teachers' English teaching practice, we completed class observations, a questionnaire, and a semi-structured interview. The observations allowed us to obtain information from the context, that is, what really happened in the classroom. For this reason, three observation sessions were held in natural environments (classrooms) in order to identify methodology and didactics used by the in-service teachers. Some main points observed included teaching strategies and techniques, classroom management, use of the second language, development of skills, and assessment. During the observation sessions, field notes were taken. In addition, a semi-structured interview was carried out to question teachers about some aspects of their teaching practice. Finally, a questionnaire was completed in order to characterize the population and their beliefs about teaching English to children.

T3 Phase II. After the diagnosis, we designed a proposal based on the reverse mentoring and peer coaching theories which was carried out during one academic semester. Within the semester, the in-service teachers observed how the pre-service teachers taught English to children during their teaching practicum and kept their own field note journals. The in-service teachers then reflected on how they could implement new practices in their classes. Once the observation process was finished, the in-service teachers filled out a questionnaire. They were asked about their perceptions related to teaching English to children, didactic strategies learned from the pre-service teachers, and also about class stages identified and skills they would like to hone.

T3 Phase III. In this phase, the peer coaching strategy was implemented. Both in-service and preservice teachers worked collaboratively in order to improve their teaching practices. Once a week the inservice teachers observed the pre-service teachers and vice-versa. Before the observations, they agreed on the aspects to be observed (pre-conference). During the observations, both the in-service and the preservice teachers took field notes (observation). Each week after the observations, teachers met to provide each other with feedback (post-conference). During the implementation of this stage, a focus group was formed in order to determine how the process was carried out. The instruments used to collect data during phases I, II and III are seen in Table 2.

Phase IV. In this stage, researchers analyzed the data collected in phases II and III. For the respective analysis, they triangulated all the data collected. Based on the analysis of the information, findings as well as conclusions were established.

\section{Findings}

During this research project, the relationship between the pre-service teachers engaged in the role of mentors and the in-service teachers who were the mentees strengthened as the attitude of both sides was open and collaborative. The former wanted to guide the in-service teachers in English teaching didactics and were willing to do so since they were aware of their needs. For this reason, they planned their lessons using a variety of strategies in order to be good models for them.

During the reverse mentoring stage, class observations done by the in-service teachers of the pre-service teachers helped them identify how to carry out the language teaching process and strategies for teaching English to children such as beginning 
Table 1: Data Collection Instruments.

\begin{tabular}{|c|c|c|c|c|}
\hline Instrument & Purpose & Number & Participants & Stage \\
\hline English proficiency Test & $\begin{array}{l}\text { To identify the linguistic competence of } \\
\text { the in-service teachers. }\end{array}$ & 1 to each teacher & In -service teachers & I \\
\hline Observation format & $\begin{array}{l}\text { To determine the in-service teachers' } \\
\text { teaching practices before having contact } \\
\text { with the pre-service teachers. }\end{array}$ & 3 to each teacher & In -service teachers & I \\
\hline Questionnaire & $\begin{array}{l}\text { To characterize the population and their } \\
\text { beliefs about teaching English to children. }\end{array}$ & 1 to each teacher & In-service teachers & I \\
\hline $\begin{array}{l}\text { Semi-structured } \\
\text { Interview }\end{array}$ & $\begin{array}{l}\text { To question teachers about some aspects } \\
\text { of their teaching practice. }\end{array}$ & 1 to each teacher & In-service teachers & I \\
\hline Journals & $\begin{array}{l}\text { To reflect on teaching strategies used by } \\
\text { pre-service teachers during the reverse } \\
\text { mentoring stage. }\end{array}$ & 1 to each teacher & In-service teachers & II \\
\hline $\begin{array}{l}\text { Feedback Written } \\
\text { Reports-Format }\end{array}$ & $\begin{array}{l}\text { To reflect about how much teaching } \\
\text { knowledge and awareness of what being } \\
\text { an English teacher involves, the in-service } \\
\text { teacher gains (R-mentoring). } \\
\text { To give feedback to the pre-service } \\
\text { teachers with the participation of the in- } \\
\text { service teachers. }\end{array}$ & $\begin{array}{l}1 \text { report every month } \\
\text { during a semester }\end{array}$ & $\begin{array}{l}\text { In-service teachers/ } \\
\text { Pre-service teachers }\end{array}$ & II \\
\hline Observation format & $\begin{array}{l}\text { To determine how the in-service and } \\
\text { pre-service teachers refine their practice } \\
\text { during the peer coaching stage. }\end{array}$ & 7 to each teacher & $\begin{array}{l}\text { In-service/pre-service } \\
\text { teachers }\end{array}$ & III \\
\hline Focus group & $\begin{array}{l}\text { To determine the benefits of peer } \\
\text { coaching if so. }\end{array}$ & 2 focus groups & $\begin{array}{l}\text { In-service/pre-service } \\
\text { teachers }\end{array}$ & III \\
\hline
\end{tabular}

the class with a warm up (e.g., songs, puzzles, videos), using flash cards and online resources, rhymes and chants for motivating students and enhancing pronunciation, using stories, puppets and class mascots as motivating strategies for presenting the new language to the students, the development of reading and listening skills through the pre, while and post activities, teaching through body movements (TPR method), assessing not only through exams but also through the process itself and using worksheets, didactic units and mini projects. Such strategies were then implemented in their classes during the peer coaching stage. It can be said that during this process, although the in-service teachers had more teaching experience than the pre-service teachers, they were able to gain specific English teaching knowledge from the less experienced teachers.

On the other hand, even though the pre-service teachers did not have much teaching experience, they had knowledge to share and were willing to do so with the in-service teachers.
The in-service teachers occasionally supported the pre-service teachers mainly on institutional procedures and other duties that experienced teachers already know; this generates a positive environment with mutual trust and respect promoting learning on both sides. This relationship allowed researchers to implement the second strategy based on the peer coaching model.

The in-service teachers' attitude facilitated this process. From the beginning of the project they were very receptive and open-minded and were aware of the importance of improving their teaching practice in order to benefit student learning.

On my part, the experience has also been positive. We have worked as a team. At the beginning I did my class in Spanish, but when I saw that the pre-service teachers did it in English, I thought: well, I will do it too! I did so and I realized that the students did understand ...You may think that they do not understand, but yes, they do. That part was amazing! (Focus group 1) 
Through the in-service teachers' field notes and also during the feedback sessions, we were able to verify the effectiveness of the reverse mentoring strategy. In their field notes, the in-service teachers reflected upon the pre-service teachers' practices and wrote comments that allowed the researchers to confirm that they had gained knowledge about it. Moreover, when the in-service and pre-service teachers met to talk about their classes, the former showed confidence in providing effective feedback to their peers. This confidence was gained after observing the pre-service teachers' practices during the reverse mentoring stage, considering that during the diagnostic stage, the in-service teachers stated that they needed to learn teaching strategies for teaching English.

During the implementation of the peer coaching strategy, both the in-service and the pre-service teachers, despite having different educational backgrounds and experiences, were able to exchange knowledge that enriched them both and gained insight from each other. In their classes, most of the in-service teachers were able to implement strategies and activities observed in their colleagues' classes and vice versa, giving them a sense of satisfaction as some had not tried these strategies before. This was evidenced by one of the teachers in the second focus group:

I think I've said this many times, but I liked that job a lot, we used to meet and plan the lessons the three of us. We three prepared and implemented the class together ... then we evaluated ourselves, I said to them what was interesting and what it was necessary to be improved. They also said to me that it was fine I was trying to talk to the children in English. Their support was excellent, they told me what to improve; it was peer work and we trusted each other. (Focus group 2)

Peer coaching provided teachers with opportunities to experience alternative strategies since they felt accompanied and in a safe environment without the pressure of being evaluated; on the contrary, they felt secure and supported by their peers. Two in-service teachers in the focus groups expressed how they felt during the observation:
"We have helped each other... we haven't felt the observation as such" (Focus group 1). "We have not felt observed... it was a kind of support and I was involved there" (Focus group 2).

The data indicated that the in-service and preservice teachers considered the implementation of the peer coaching strategy as a way to learn from each other. The in-service teachers perceived it as something they needed to do in order to improve their teaching practices; in fact, they considered the project a great opportunity for professional development in which their needs were considered. Due to this fact, they were very engaged and committed during the process. Conversely, the pre-service teachers saw the project as a privilege to gain knowledge from an experienced teacher. In this exchange of knowledge and skills, the in-service teachers gained insight into how to teach English using strategies and procedures that favored their students' learning process such as the use of visual aids as flashcards, videos, and posters, among others as tools to keep students focused; the use of games and dynamic activities were found interesting considering that children enjoy playing and having fun during their learning process; the use of L2 in the classroom as a way to provide input to students; the development of language skills and their different stages; the connection of cross curricular topics in the English class in order to develop not only language skills, but also thinking skills and the inclusion of cultural elements when teaching a foreign language among others. Likewise, the pre-service teachers identified and recognized diverse strategies for classroom management being one of the weaknesses at the beginning of the process. This was reflected in the field notes taken by the preservice teachers during class observation: "The class was organized and there were good activities. When students misbehaved, the teacher quickly gained the control and continued with her class... At the first sign of indiscipline she calls students' attention" (Field notes 1).

This shows that during the peer coaching work, the pre-service teachers learned classroom management strategies from the in-service teachers. First, they were aware of the importance of being consistent with the classroom agreements made by the students and teachers at the beginning 
of the school year. Being firm with these procedures allowed the group of pre-service teachers to have efficient classroom management that ended in a favorable class atmosphere in which activities were successfully implemented.

In addition, during the peer coaching work, the in-service teachers learned the identification of some stages and how they could be developed with the purpose of making the English teaching process more meaningful. Despite knowing how to plan a lesson, they were also able to learn the key moments of an English class from the lesson planning format used by the pre-service teachers. These include: the lesson opening, the warmup activities, the procedure, the assessment, and the closure. They learned that at the beginning of the lesson, it is necessary to use routines that help students get familiar with the language. Furthermore, they determined that the warm up activities serve to introduce the topic of the class in a dynamic and meaningful way for students and to engage them in the class. Concerning the procedure, they concluded that teaching English to children requires a methodology that includes a variety of activities according to their age and grade level. The in-service teachers became aware of the importance of using a lot of resources and materials to keep students focused and interested in the topic. Regarding assessment, they learned that this can be done through the use of various activities and not only through the use of tests.

Among the routines they did (pre-service teachers) there were some moments in which they motivated students, arranged the classroom and presented the agenda with the activities to develop in the class. They also explained the topic based on some materials designed by them and developed the topic using some worksheets... and at the end, they assessed students either with a game, with a dynamic activity or with a worksheet assigned to reinforce the topic or to evaluate if children had grasped the topic or had had difficulties to work on them the next class. (Focus group 2)

Most of the in-service teachers did not have the English proficiency level to teach English as per the results of the English test administered at the beginning of the diagnosis. Despite this fact, they made their effort in each session to improve their praxis making use of technological and online resources and also based on the support of their colleagues, and the pre-service teachers when they did not feel confident about issues related to pronunciation and vocabulary. Nevertheless, they were aware of the need to continue working on those linguistic aspects. A teacher shared her experience:

I tried to teach all the class in English... I do not speak English, but well... I thought that the pre-service teachers were going to be there and they could tell me what I pronounced correctly or incorrectly... because they already speak the language. (Focus group 1)

Another relevant aspect found during the implementation of the peer coaching strategy was that although the peer-coaching model in this study proposed the adoption of the three basic steps (preconference, observation and post-conference), a group of in-service and pre-service teachers agreed on lesson planning together. This implied choosing a date to sit down and work together on the lesson plan, proposing the activities and strategies, and even selecting or designing the material to be used for the following session. This fact made the participants feel as though they could contribute to each other and to have a higher sense of confidence, especially for the in-service teacher. The following was expressed by an in-service teacher:

Well, the experience last year was very interesting. In my case, I could participate during the session the pre service teachers gave. I mean, there was collaborative work between them and me. The lesson planning was made in team, so it was an enriching experience for all of us...Something that I think it was quite interesting was that we designed a lot of materials together. (Focus group 2)

There were some limitations such as the time for feedback sessions due to the fact that students should always be supervised and accompanied by a teacher. Despite the fact that the in-service teachers could participate in the peer coaching 
phase without taking extra time out of their work, they were restricted to the classrooms at all times, preventing them from exchanging more with their peers or having additional training. However, the preservice teachers took turns accompanying children in order for the in-service teachers to carry out the feedback sessions. This is what an in-service teacher expressed about having time for feedback sessions:

but I think that the moments we shared with the pre-service teachers were not enough, they already know the English didactics and could have given us more insight on how to teach the language, but we know that it was due to the lack of time... it was time constrains... but as I was saying, related to English didactics, they know more and have more experience than us. (Focus group 2)

An additional limitation had to do with the lack of some technical resources inside the classrooms in order to project and share in a more practical way the didactic material prepared by the teachers. The school had a computer room, but it was difficult to access by the pre-service teachers the days they went to the school as it was already assigned to other teaches. Despite these drawbacks, there were many positive aspects in this process such as voluntary involvement on the part of the teachers, collaboration, and over all, their desire to learn and improve their teaching practice. On the other hand, pre-service teachers were ready to support in-service teachers and also gained knowledge from their teaching experience.

\section{Conclusions}

In Colombia there have been some challenges and attempts to improve the level of English of students throughout the nation. The government has invested in qualifying teachers, but the coverage has not been enough. Hence, it is essential to continue supporting in-service teachers, especially those from public elementary schools where teachers have to teach all subjects including English as a foreign language.

Thus, to strengthen pedagogical practices, especially in the English teaching field, it is necessary to implement strategies which take into account the specific needs of the teachers and the learners in order to have more realistic, meaningful, and successful processes. Due to the lack of professional development opportunities that some elementary school teachers have in the English teaching field, reverse mentoring and peer coaching appear to be strategies that foster professional development effectively.

Several professional development programs have been carried out based on the traditional conception of mentoring in which a senior expert provides the mentees with their knowledge and experience of their field. However, in this study reverse mentoring was something innovative since the in-service teachers with teaching experience could gain knowledge about English didactics and refine their English teaching skills from the preservice teachers who were novice but possessed specific knowledge on this particular subject.

Reverse mentoring has been mainly used in the technological domain in which millennials have developed many skills that senior workers have not, but in our study, the use of reverse mentoring was focused on the development of teaching skills in the English teaching and learning field as it was the need of the group of participants who, in spite of having pedagogical knowledge, did not have the specific expertise in the English area as they were not English teachers. Thus, this strategy of professional development allowed the in-service teachers to recognize, through the observation of the pre-service teachers' classes and their own reflection of their teaching practice, some classroom strategies and activities that were successful for teaching English to children.

In addition to reverse mentoring, in this study peer coaching answered the purpose of supporting a group of in-service elementary school teachers to strengthen their English teaching practice through the collaborative work with pre-service teachers. This collaborative work became a professional development strategy since the participants were able to enhance their knowledge about the teaching profession from each other and test new teaching tools, techniques, and strategies with their students. 
Peer coaching was valuable to create a professional development opportunity for the group of participants in their workplace. As Zwart et al. (2008) state, "the coaching trajectory is a work-based learning environment in which pairs of teachers can work together to support each other's professional growth with respect to some issues already present in their day-today teaching process" (p. 983). This kind of professional relationship fostered and benefitted teachers' professional growth in a cohesive form.

Additionally, in our research project the roles played by the participants during the peer coaching sessions were not the ones in which one becomes the coach while the observer becomes the coached; instead, the roles were reversed. The teachers observed each other on a weekly basis and the coach was no longer the coach, rather, they became peers as they interacted, exchanged knowledge and experience, and reflected upon their practice becoming a learning community. According to Goker (2005):

one strategy for teacher development particularly well suited to formation of a reflective learning community is that of peer coaching defined as the process of two teachers working together in and out the classroom to plan instruction, develop support materials and watch one another work with students. Peer coaching is non-evaluative, based on classroom observation followed by feedback and intended to improve specific instructional techniques. (p. 240)

Likewise, the participants' relationship was developed in a trustworthy and open environment in which mutual enrichment and support were the basis; for this reason, they were very committed throughout the process. Importantly, communication was a key factor to keep that harmonic relationship. The participants communicated with each other freely and respectfully inside and outside the classroom. So, it is useful to encourage professional conversations and dialogues that help teachers not only to reflect about their practice, but also to share their best practices and successful instruction. Robbins (1991) claims: despite hundreds of years of collective expertise in individual schools, few avenues exist for teachers to tap this expertise. One argument in the case of peer coaching is that it offers a way to break the isolation and tap craft knowledge of others. But this requires that teachers relate to one another in a collegial way, sharing their knowledge about teaching across classrooms. Many teachers have never experienced this type of interaction. (pp. 10-11)

In this regard, it is important to note that the relationship between the participants was constructive since from the beginning both the pre-service and the in-service teachers had an attitude of openness and welcome towards the other as they considered that collaborative work would allow them to grow mutually. Both groups benefitted-the in-service teachers constructed knowledge about teaching English to children and the pre-service teachers benefitted from gaining knowledge of the school and also some procedures that teachers should follow in their everyday job such as classroom management and other duties.

Furthermore, even though there have been previous studies on reverse mentoring and peer coaching, the model used in this study in which preservice and in-service teachers work collaboratively has not been very common. In most cases, these strategies have been given among colleagues, that is, between in-service teachers with teaching experience or between only pre-service teachers like the study carried out by Goker (2005) in which peer coaching was used with two groups of student teachers.

Nevertheless, it is important to note this model can be implemented within the pre-service teaching practicum in different areas where it is sought to improve teachers' practice and to encourage collaborative work between in-service and pre-service teachers, as well as to prepare pre-service teachers for their professional life, update in-service teachers' practices, deepen their pedagogical knowledge in the English teaching field, and contribute with their professional growth. 


\section{Limitations}

Although it was a rewarding experience considering the participants' growth as it was observed along the implementation of the project, there were some limitations that did not allow us to achieve the goal easily. The lack of time for the feedback sessions, the focus groups, and the meetings among the participants was one of the main limitations as long as they were carried out during the teachers' working time. As the in-service teachers who participated in this research project were not language teachers, it is suggested to continue with their language training in order to improve their English proficiency level since it was another limitation for many of them. Due to this lack of linguistic knowledge, they sometimes felt fear when using the L2 and so the students did not have too much meaningful exposure to the target language.

\section{Further Research}

Matters like the previous ones should encourage educators to continue working on professional development proposals in favor of the needs that some elementary school teachers have in Colombia and thus benefit the students learning English as a foreign language. Proposals as such should be developed as part of the teachers' schedule in order to work collaboratively with the educational institution and to count with the necessary education authorities' support. Finally, it would also be advisable to keep working on reverse mentoring strategies not only with elementary school teachers, but also with teachers of secondary education with the purpose of updating or complementing their teaching practices within a professional collaborative framework.

\section{References}

Álvarez Valencia, J. A., Cárdenas Beltrán, M. L., \& González Moncada, A. (2015). Cobertura vs continuidad: Dos retos para el desarrollo profesional para los docentes de inglés en el marco de Colombia Bilingüe. In G. M. Jesús Alirio Bastidas (Ed.), Fundamentos para el Desarrollo Profesional de los Profesores de Inglés (p. 169-221). Nariño: Editorial Universitaria-Universidad de Nariño.
Anderson, N. A., Caswell, I. J., \& Hayes, M. E. (1994). Using peer coaching to provide

additional feedback to preservice teachers of reading in an early field experience. In E. G. Sturtevant $\mathcal{E}$ W. M. Linek (Eds.), Pathways for literacy: Learners teach and teachers learn (pp. 211-221). Pittsburg, KS: College Reading Association.

Bowman, C. L., \& McCormick, S. (2000). Comparison of peer coaching versus traditional supervision effects. The Journal of Educational Research, 93(4), 256-261. https://doi. org/10.1080/00220670009598714

Bozeman, B., E Feeny, M. (2007). Toward a useful theory of mentoring. Administration and Society, 39(6), 719739. https://doi.org/10.1177/0095399707304119

Brewer, A. (2016). Mentoring from a positive psychology perspective. Learning for mentors and mentees. Switzerland: Springer. https://doi.org/10.1007/978-3319-40983-2

Briggs, M., \& Van Nieuwerburgh, C. (2010). The development of peer coaching skills in primary school children in years 5 and 6. Procedia Social and Behavioral Sciences, 9, 1415-1422. https://doi. org/10.1016/j.sbspro.2010.12.343

Britton, L. R., E Anderson, K. A. (2010). Peer coaching and pre-service teachers: Examining an underutilised concept. Teaching and Teacher Education, 26, 306314. https://doi.org/10.1016/j.tate.2009.03.008

Buzbee Little, P. (2005). Peer coaching as a support to collaborative teaching. Mentoring $\mathcal{E}$ tutoring: Partnership in learning, 13(1), 83-94. https://doi. org/10.1080/13611260500040351

Cárdenas, M. L., González, A., \& Alvarez, J. A. (2010). El desarrollo profesional de los docentes de inglés en ejercicio: Algunas consideraciones conceptuales para Colombia. Folios, 31(1), 49-68. https://doi. org/10.17227/01234870.31folios49.67

Cárdenas, R., \& Miranda, N. (2014). Implementación del programa nacional de bilingüismo en Colombia: Un balance intermedio. Educ.Educ., 17(1), 51-67. https://doi.org/10.5294/edu.2014.17.1.3

Cely, R.M., (2007). Una Colombia Bilingüe. Entrevista con Rosa María Cely. Eleducador.com. Retrieved from: http:// www.eleducador.com/col/contenido/ contenido.aspx? catID =107EconID=205

Chavez, O. E Fernández, A. (2016). A didactic proposal for EFL in a public school in Cali. How, 23(1), 10-19

Cornett, J., E Knight, J. (2009). Research on coaching. In J. Knight (Ed.), Coaching: Approaches and perspectives (pp. 192-216). Thousand Oaks, CA: Corwin Press. 
Correa, D., E González, A. (2016). English in public primary schools in Colombia: Achievements and challenges brought about by national language education policies. Education Policy Analysis Archives, 24(83), 1-26. https://doi.org/10.14507/epaa.24.2459

Creswell, J. (2014). Research design: Quantitative, qualitative and mixed methods approaches. Nebraska: SAGE Publications Inc. https://doi. org/10.1016/j.sbspro.2013.10.001

Devine, M., Houssemand, C., \& Meyers, R. (2013). Instructional coaching for teachers: A strategy to implement new practices in the classrooms. Procedia Social and Behavioral Sciences, 93, 1126- 1130. https://doi.org/10.1016/j.sbspro.2013.10.001

Díaz-Maggioli, G. H. (2003). Professional development for language teachers. Eric Digest EDO-FL-03-03. Retrieved from: http://www.cal.org/resource-center/ resource-archive/digests.

Duncan, H. E., E Stock, M. J. (2010). Mentoring and coaching rural school leaders: What do they need? Mentoring \& Tutoring: Partnership in Learning, 18, 293-311. https://doi.org/10.1080/13611267.2010.4 92947

Goker, S. (2005). Impact of peer coaching on self-efficacy and instructional skills in TEFL teacher education. System, 34, 239-254. https://doi.org/10.1016/j. system.2005.12.002

González, A., Montoya, C., \& Sierra, N. (2002). What do EFL teachers seek in professional Development Programs? Voices from Teachers. Íkala, 7(13), 3050 .

González, A. (2007). Professional development of EFL teachers in Colombia: Between colonial and local practices. Íkala, 12(18), 309-332.

Greengard, S. (2002). Moving forward with reverse mentoring. Workforce, 81(3), 15.

Hewlett, S. A., Sherbin, L., \& Sumberg, K. (2009a). How Gen Y and Boomers will reshape your agenda. Harvard Business Review, 8(7/8), 71-76.

Hewlett, S. A., Sherbin, L., \& Sumberg, K. (2009b). Let Gen Y teach you tech. Harvard Business Review. Retrieved from: https://hbr.org/2009/06/let-gen-yteach-you-tech

Kram, K., \& Isabella, L. (1985). Mentoring alternatives: The role of peer relationships in career development. Academy of Management Journal, 28(1), 110-132.
McNulty, M., \& Quinchía, D. I. (2007). Designing a holistic professional development program for elementary school English teachers in Colombia. Profile, 8(1), 131-143.

Meister, J. C., \& Willyerd, K. (2010). Mentoring millennials. Harvard Business Review, 88(5), 67-72.

Ministerio de Educación Nacional (MEN). (1999). Lineamientos curriculares idiomas extranjeros. Bogotá: Enlace Editores.

Murphy, W. (2012). Reverse mentoring at work: Fostering cross-generational learning and developing millennial leaders. Human Resources Management, 51(4), 549-574. https://doi.org/10.1002/hrm.21489

Richards, J. C. E Farrell, T. S. (2005). Professional development for language teachers: Strategies for teacher learning. USA: Cambridge University Press. https://doi.org/10.1017/CBO9780511667237

Robbins, P. (1991). How to plan and implement a peer coaching program. Virgina: ASCD.

Showers B., \& Joyce B. (1996). The evolution of peer coaching. Improving Professional Practice, 53(6), 12-16.

Wanberg, C. R., Welsh, E. T., \& Hezlett, S. A. (2003). Mentoring research: A review and dynamic process model. Research in Personnel and Human Resources Management, 22, 39-124. https://doi.org/10.1016/ S0742-7301(03)22002-8

Zauschner-Studnicka, S. (2017). A model for reversementoring in education. International Journal of Social, Behavioral, Educational, Economic, Business and Industrial Engineering, 11(3), 546 $-553$.

Zwart, R., Wubbels, T., Bergen, T., E Bolhuis, S. (2008). Teacher learning through reciprocal peer coaching: an analysis of activity sequences. Teaching and Teaching Education, 24(4), 982-1002. https://doi. org/10.1016/j.tate.2007.11.003

Zwart, R., Wubbels, T., Bergen, T., \& Bolhuis, S. (2009). Which characteristics of a reciprocal peer coaching context affect teacher learning as perceived by teachers and their students? Journal of Teacher Education, 60(3), 243-257. https://doi. org/10.1177/0022487109336968 